\title{
The Historical Practice of "Membrane Sweep" to Initiate Labour: Does it Have a Role in Contemporary Obstetric Practice?
}

\author{
Suganya Sukumaran ${ }^{1}$ and Edwin Chandraharan ${ }^{2 *}$ \\ ${ }^{1}$ Obstetrics \& Gynaecology, South Warwickshire NHS Foundation Trust, UK \\ ${ }^{2}$ Global Academy of Medical Education \& Training, Basildon University Hospital, UK
}

Submission: February 15, 2021; Published: March 04, 2021

*Corresponding author: Edwin Chandraharan, Director, Global Academy of Medical Education \& Training, London \&, Consultant Intrapartum Care Advisor, Basildon University Hospital, Mid and South Essex NHS Foundation Trust, Essex, UK

\begin{abstract}
The "membrane sweep" or artificial separation of membranes (ASOM) was introduced into clinical practice to artificially initiate labor, and to avoid the risks of a prolonged pregnancy. In the absence of other chemical and mechanical methods to ensure cervical ripening, the "Membrane Sweep" became established in obstetric practice for approximately 200 years. Cochrane Systematic Review in 2001 [1] questioned the efficacy of the "Membrane Sweep", as the likelihood of a spontaneous labor was found to be very modest and with no reduction in operative deliveries or an increase in spontaneous vaginal births following ASOM. On the other hand, there are potential risks of introducing bacteria from the maternal vagina into the chorio-decidual space, increasing the risks of inflammation and infection. We have analyzed the current systematic evidence on the "Membrane Sweep" to determine its efficacy. Midwives and obstetricians owe their patients a duty of care to weigh the reported benefits of the ASOM against the potential risks of fetal infection, whilst recommending this historical practice which was introduced prior to the advent of chemical (e.g., prostaglandins), or mechanical (e.g., cervical balloon catheters) methods, in contemporary obstetric practice.
\end{abstract}

Keywords: Artificial separation of membranes; Membrane sweep; Ascending infection; Zig Zag Pattern; Prostaglandins; Colonization

Abbreviations: CTG: Cardiotocograph; NHS: National Health Service; ASOM: Artificial Separation of Membranes; GBS: Group -B, Streptococcus

History and Practice of "Membrane sweeping" (Artificial Separation of Membranes or "ASOM")

Membrane stripping or sweeping involves a vaginal examination during which a finger is introduced into the cervical os to separate the membranes from the lower uterine segment by a circular movement. Membrane sweeping was first suggested by James Hamilton in 1810 [2] for labor induction. Mc Colgin [3] confirmed that the membrane sweep was associated with an increased activity of prostaglandin F2 and phospholipase A. A Bishop's score [4] to assess the cervical length, dilatation, effacement, consistency position of cervix and fetal descent is used to predict the prognosis of the membrane sweep and the induction process.

What are the Potential Risks of the "Membrane Sweeping"?

The mucosa of the vagina is continuous with the skin of the thigh, perineum and has an anatomical proximity to the anal canal and the rectum. The pregnant uterus is anatomically connected to the vagina through the cervix. This makes it more susceptible to colonization and infection by bacteria that normally reside in the vagina and rectum during pregnancy and in labor. The function of the cervix is to provide mechanical strength to retain the growing fetus until term. In addition, a long and a closed uterine cervix along with the mucous plug within the cervical canal provides a mechanical barrier which prevents any ascending infection from the vagina into the amniotic cavity [5]. However, recent evidence has shown that the endocervical epithelium and the cervical mucous plug have significant innate and adaptive immune functions [6]. Any disturbance to the closed cervix can lead to dislodgement of the protective mucous plug and thereby promoting the microbial ascent through the cervix into the amniotic cavity (Figure 1). Approximately 40 years ago, it was shown that bacteria could cause intra-amniotic infection even in the presence of "intact" amniotic membranes [7]. It has also been reported that markers of inflammation found within the amniotic cavity in approximately 


\section{Global Journal of Reproductive Medicine}

$26 \%$ of suspected cases of intra amniotic infection following amniocentesis in women without the rupture of membranes [8]. It has also been shown that the degree of severity of intra-amniotic infection correlates to poor neonatal outcomes [9]. Therefore, the earlier assumption that the likelihood of intra-amniotic infection was low due to the "mechanical barrier" provided by the amniotic membranes when the "Membrane Sweep" was introduced into clinical practice 200 years ago, can no longer be accepted in the light of current scientific evidence. Therefore, one should not fall prey to the false sense of reassurance by assuming that the ASOM is safe, because the amniotic membranes are intact. Several studies have confirmed that the presence of inflammatory mediators within the amniotic cavity is associated with perinatal brain injury [10-13]. During the ASOM, it is likely that many organisms may be introduced by the clinician's finger, through the cervical canal, adjacent to amniotic membranes. Therefore, the "bacterial load" that would initiate the inflammation and subsequent infection would be much higher following the "Membrane Sweep". It is well known that in addition to the virulence of the organism, the bacterial load is an independent risk factor which increases the severity of any infection in humans. Moreover, studies show that Prostaglandin F 2 Alpha was elevated in $40.2 \%$ of women who had preterm labor with intact membrane and was an independent risk factor for intra amniotic inflammation and infection [14]. As ASOM has been shown to release prostaglandins in term pregnancies, it may increase the likelihood of intra amniotic inflammation and infection.

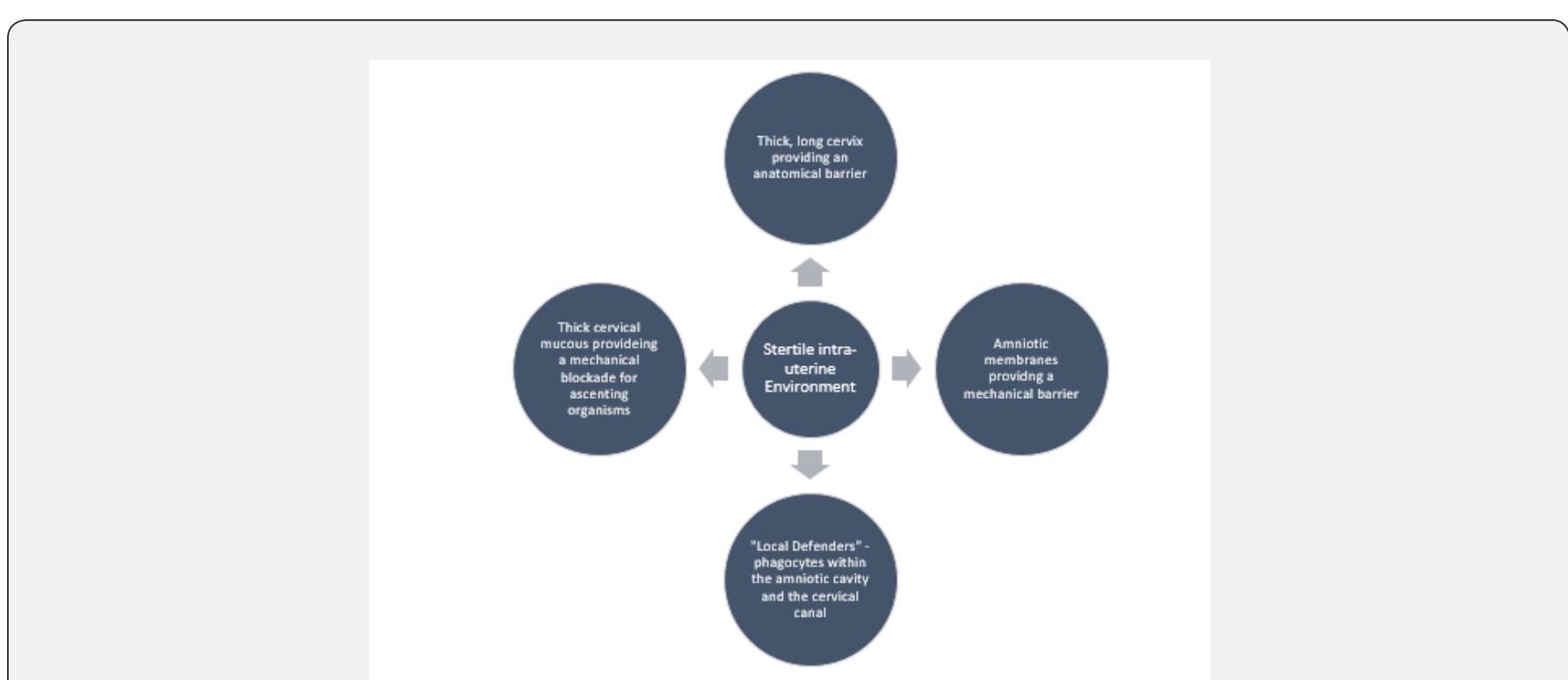

Figure 1: Factors which prevent intra-uterine infection during pregnancy.

Scientific Evidence Regarding the Effectiveness of "Membrane Sweeping"

A recent Cochrane review [15] suggested that the women who had membrane sweep were more likely to have spontaneous onset of labor but found no clear difference in unassisted vaginal births. There were no clear differences between the groups for caesarean section, instrumental vaginal births or serious illness or death of the mother or baby. NICE guidelines recommend that the women should be offered a membrane sweep as an adjunct to formal induction of labor [16]. The STRIP-G study showed an adverse neonatal outcome in $5.9 \%$ of cases in women with vaginal colonization of Group B Streptococcus (GBS) identified on a high vaginal swab [17]. It is important to appreciate that the recent Cochrane Review [15] which compared membrane sweep with no or sham treatment concluded that the likelihood of spontaneous labour following the membrane sweep was only $21 \%$. There was no statistically significant difference in the rate of caesarean sections or perinatal outcomes. A recent randomized controlled study [18] has concluded that the difference in onset of spontaneous labor in those who underwent a "membrane sweep" was only $15 \%$.

\section{What do Observational Data Show?}

In the United Kingdom, the ASOM is widely practiced, despite the Cochrane Systematic Review concluding in 2001 [1] that "Routine use of sweeping of membranes from 38 weeks of pregnancy onwards does not seem to produce clinically important benefits". The "Early Notification Report" from the NHS Resolution has highlighted in 2019 that perinatal infection was responsible for $15.6 \%$ of all admissions to the neonatal unit in the UK [19]. We conducted an observational study in 57 cases of confirmed acute chorioamnionitis, by placental histopathology results over a period of 6 years (Unpublished Data). Out of the 57 women, 50 


\section{Global Journal of Reproductive Medicine}

(87.7\%) did have a membrane sweep between 24-48 hours of birth and 54 women (94.7\%) had a caesarean section with their babies being admitted to the neonatal unit for suspected or confirmed sepsis receiving antibiotics. 47 women (87\%) were readmitted with wound infection. Because the "Membrane Sweep" is widely practiced in the UK, the data from the NHS Resolution, and our retrospective observational study (Unpublished Data) suggest the need to re-visit this historical practice. Whilst it may continue to have a place in obstetric practice in low-resource settings, where prostaglandins are not freely available for induction of labour due to costs due to the potential detrimental effects (Table 1), the continued use of the ASOM in well-resourced settings need to be questioned. Most of the current guidelines on CTG Interpretation have been designed to detect intrapartum hypoxia and not fetal sepsis, the CTG abnormalities observed in chorioamnionitis such as absence of cycling and the "Zig Zag" Patterns [20-21] may be easily missed. if guidelines such as the NICE which are based on "pattern recognition"with arbitrary parameters are used. Therefore, fetuses with ongoing inflammatory damage or chorioamnionitis following the "Membrane Sweep" may be missed at the time of admission or during labor.

Table 1: Potential detrimental effects of the "Membrane Sweep".

\begin{tabular}{|c|c|c|}
\hline Action & Detrimental Effects & Possible Harm \\
\hline $\begin{array}{l}\text { Clinician's finger is inserted } \\
\text { through the cervical canal to } \\
\text { reach the amniotic mem- } \\
\text { branes }\end{array}$ & Disruption of cervical mucous & $\begin{array}{l}\text { Introduction of the bacteria from the maternal vagina into } \\
\text { the space above the internal cervical os }\end{array}$ \\
\hline \multirow{3}{*}{$\begin{array}{l}\text { "Sweeping Action" of the cli- } \\
\text { nician's finger, separating the } \\
\text { membranes from the cervix" }\end{array}$} & a) Release of local prostaglandins & $\begin{array}{l}\text { Likely increase in local inflammatory response, and the } \\
\text { negative impact of inflammatory mediators on the fetus }\end{array}$ \\
\hline & $\begin{array}{l}\text { b) Bleeding from the cervical venous sinuses } \\
\text { as a result of the mechanical trauma as a } \\
\text { result of the "Membrane Sweep" }\end{array}$ & $\begin{array}{l}\text { Blood is a good culture medium for bacteria, and it also } \\
\text { provides neutrophils and phagocytes, at the site of amniotic } \\
\text { membranes, which can initiate an inflammatory response. }\end{array}$ \\
\hline & $\begin{array}{c}\text { c) A "large dose" of the bacteria is pushed above the } \\
\text { internal cervical os }\end{array}$ & $\begin{array}{l}\text { Possibility of over-riding fetal host response, and causing } \\
\text { inflammation and infection }\end{array}$ \\
\hline $\begin{array}{l}\text { Delayed time interval between } \\
\text { the "Membrane Sweep" and } \\
\text { the onset of labourd time } \\
\text { interval between the "Mem- } \\
\text { brane Sweep" and the onset } \\
\text { of labour }\end{array}$ & $\begin{array}{l}\text { A longer incubation period which facilitates the colo- } \\
\text { nisation and growth of organisms, when the woman } \\
\text { is sent home, and not monitored. }\end{array}$ & $\begin{array}{l}\text { Possible increase in the risks of maternal and fetal infec- } \\
\text { tion. }\end{array}$ \\
\hline
\end{tabular}

\section{Conclusion}

Membrane sweep was introduced into clinical practice in the 17 th century before the availability of chemical or mechanical methods for cervical ripening. However, in modern obstetric practice, these are freely available in well-resourced settings. Therefore, the continued historical practice of the "Membrane sweep" which could not only lead to interruption in the barrier mechanism provided by the uterine cervix, but can also cause other detrimental effects, should be questioned. The magnitude of benefit of initiating a spontaneous onset of labour (approximately $21 \%$ ), should be weighed against potential harmful effects (Table 1) of the "Membrane Sweep", and women should be counselled accordingly. Evidence-based clinical practice should always trump historical obstetric practices with unproven benefits and potential risks to ensure "first do no harm" to our patients.

\section{References}

1. Boulvain M, Stan CM, Irion O (2001) Membrane sweeping for induction of labour. Cochrane Database of Systematic Reviews 2(1): CD000451.
2. Krammer J, O Brien WF (1995) Mechanical methods of cervical ripening. Clin Obstet Gynecol 38: 280-286.

3. McColgin SW, Bennett WA, Roach H, Cowan BD, Martin JN, et al. (1993) Parturitional factors associated with membrane stripping. Am J Obstet Gynecol 169: 71-77.

4. Bishop EH (1964) Pelvic scoring for elective induction. Obstet Gynecol 24: 266-268.

5. Ludmir J, Sehdev HM (2014) Anatomy and physiology of the uterine cervix. Clin Obstet Gynecol 43: 433-439.

6. Word RA, Li XH, Hnat M, Carrick K (2017) Dynamics of cervical remodeling during pregnancy and parturition: mechanisms and current concepts. Semin Reprod Med 25(1): 69-79.

7. Miller JM, Pupkin MJ, Hill GB (1980) Bacterial colonization of amniotic fluid from intact fetal membranes. Am J Obstet Gynecol 136(6): 796804.

8. Myntti T, Rahkonen L, Nupponen I, Pätäri Sampo A, Tikkanen M, et al. (2017) Amniotic Fluid Infection in Preterm Pregnancies with Intact Membranes. Dis Markers 2017: 8167276.

9. Combs CA, Gravett M, Garite TJ, Hickok DE, Lapidus J, et al. (2014) Amniotic fluid infection, inflammation, and colonization in preterm labor with intact membranes. Am J Obstet Gynecol 210(2): 125.e1-125. 
10. McAdams RM, Juul SE (2012) The role of cytokines and inflammatory cells in perinatal brain injury. Neurol Res Int 2012: 561494.

11. Hagberg H, Mallard C, Ferriero DM, Vannucci SJ, Levison SW, et al. (2015) The role of inflammation in perinatal brain injury. Nat Rev Neurol 11(4): 192-208.

12. Sävman K, Blennow M, Gustafson K, Tarkowski E, Hagberg H (1998) Cytokine response in cerebrospinal fluid after birth asphyxia. Pediatr Res 43:746-751.

13. McAdams RM, Juul SE (2012) The role of cytokines and inflammatory cells in perinatal brain injury. Neurol Res Int 2012: 561494.

14. Park JY, Romero R, Lee J, Chaemsaithong P, Chaiyasit N, et al. (2016) An elevated amniotic fluid prostaglandin F2 $\alpha$ concentration is associated with intra-amniotic inflammation/infection, and clinical and histologic chorioamnionitis, as well as impending preterm delivery in patients with preterm labor and intact membranes. J Matern Fetal Neonatal Med 29(16): 2563-2572.

15. Finucane EM, Murphy DJ, Biesty LM, Gyte GML, Cotter AM, et al. (2020) Membrane sweeping for induction of labour. Cochrane Database of Systematic Reviews 2(1): CD000451.
16. (2008) National Institute for Health and Care Excellence. Inducing Labour. CG70. NICE.

17. Kabiri D, Hants Y, Yarkoni TR, Shaulof E, Friedman SE, et al. (2015) Antepartum Membrane Stripping in GBS Carriers, Is It Safe? (The STRIP-G Study). PLoS ONE 10(12): e0145905.

18. Zamzami, T, Al Senani N (2014) The Efficacy of Membrane Sweeping at Term and Effect on the Duration of Pregnancy: A Randomized Controlled Trial. Journal of Clinical Gynecology and Obstetrics, North America.

19. (2019) The Early Notification scheme progress report: collaboration and improved experience for families

20. Pereira S, Chandraharan E (2017) Recognition of chronic hypoxia and pre-existing foetal injury on the cardiotocograph (CTG): Urgent need to think beyond the guidelines. Porto Biomed J 2(4): 124-129.

21. Galli L, Dall Asta A, Whelehan V, Archer A, Chandraharan E (2019) Intrapartum cardiotocography patterns observed in suspected clinical and subclinical chorioamnionitis in term fetuses. J Obstet Gynaecol Res 45(12): 2343-2350.

Your next submission with Juniper Publishers
will reach you the below assets
- Quality Editorial service
- Swift Peer Review
- Reprints availability
- E-prints Service
- Manuscript Podcast for convenient understanding
- Global attainment for your research
- Manuscript accessibility in different formats
( Pdf, E-pub, Full Text, Audio)
- Unceasing customer service
Track the below URL for one-step submission
https://juniperpublishers.com/online-submission.php

